2. To: (Receiving Organization)

Distribution

5. Proj./Prog./Dept./Div.:

TWRS Nuclear Safety \& Licensing

8. Originator Remarks:

This document implements the TWRS facility specific independent and internal criticality safety inspections.

11. Receiver Remarks:

11A. Design Baseline Document?

[] Yes

$[\mathrm{X}]$ No
3. From: (originating organization) Criticality Support

6. Design Authority/ Design Agent/Cog. Engr.:

T. S. Vail
4. Related EDT No.:

N/A

7. Purchase Order No.:

N/A
9. Equip./Component No.:

$\mathrm{N} / \mathrm{A}$

10. System/Bldg./Facility: TWRS

12. Major Assm. Dwg. No.: $N / A$

13. Permit/Permit Application No.: $N / A$

14. Required Response Date:

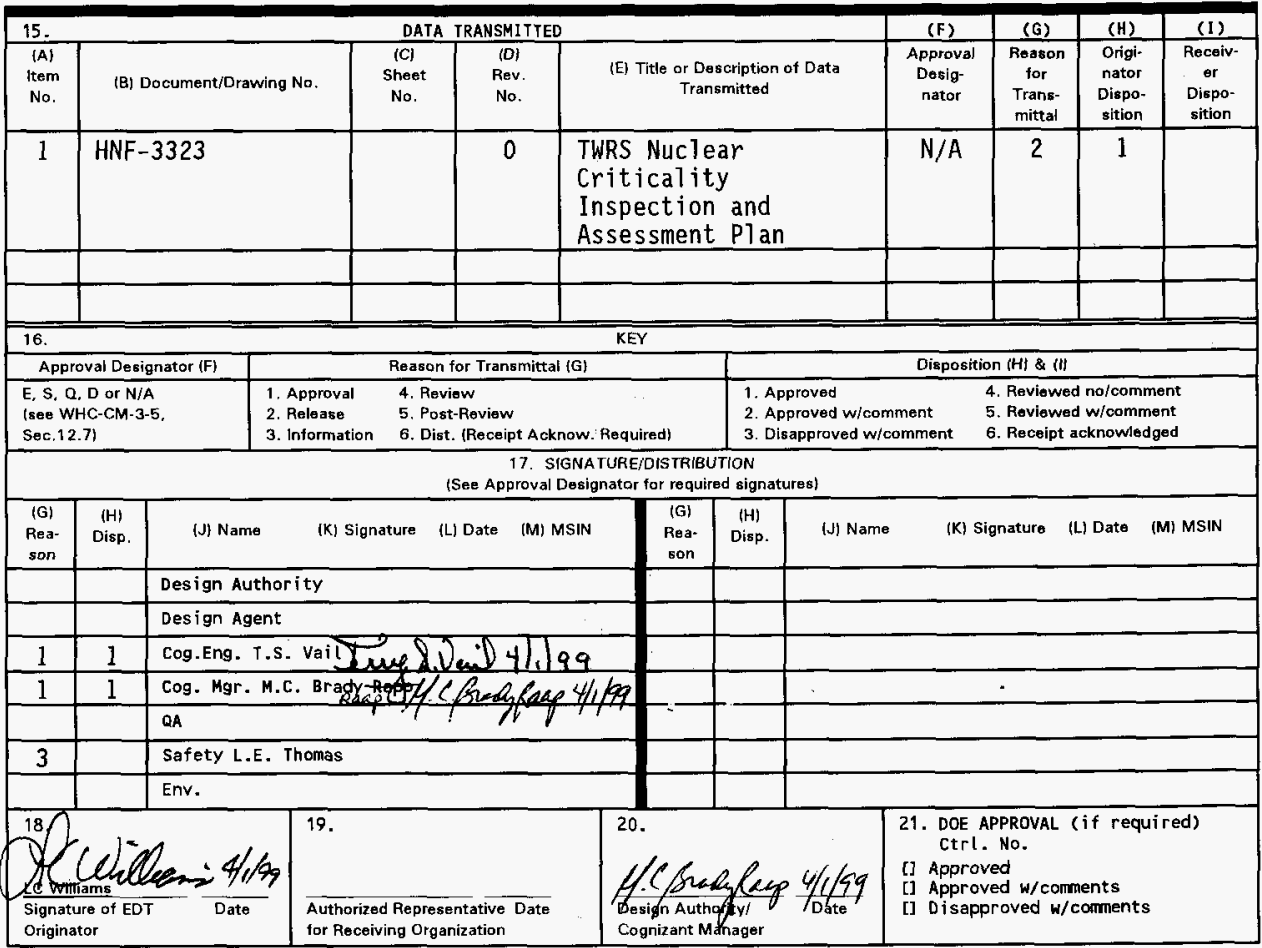

BD-7400-172-2 (05/96) GEF097 


\title{
TANK WASTE REMEDIATION SYSTEM NUCLEAR CRITICALITY SAFETY INSPECTION AND ASSESSMENT PLAN
}

M. C. Brady Raap and $T$. S. Vail

Duke Engineering and Services Hanford, Inc.,

Richland, WA 99352

U.S. Department of Energy Contract DE-AC06-96RL13200

$\begin{array}{lll}\text { EDT/ECN: } 619460 & \text { UC: } 610 \\ \text { Org Code: } & \text { 2N500 } & \text { Charge Code: } 101964 \mathrm{BB} 30 \\ \text { B\&R Code: } & \text { EW3120072 } & \text { Total Pages: } \mathbf{2 4}\end{array}$

Key Words:

TWRS Criticality Safety, safety issue, assessment, inspection

\begin{abstract}
:
This plan provides a management approved procedure for inspections and assessments of sufficient depth to validate that the Tank waste

Remediation System (TwRS) facility complies with the requirements of the Project Hanford criticality safety program, HNF-PRO-334, "Criticality Safety General, Requirements:".
\end{abstract}

TRADEMARK DISCLAIMER, Reference herein to any specific commercial product, process, or service by trade name, trademark, manufacturer, or otherwise, does not necessarily constitute or imply its endorsement, recommendation, or favoring by the United States Government or any agency thereof or its contractors or subcontractors.

Printed in the United States of America. To obtain copies of this document, contact: Document Control Services, P.O. Box 950, Mailstop H6-08, Richland WA 99352. Phone (509) 372-2420; Fax (509) 376-4989.
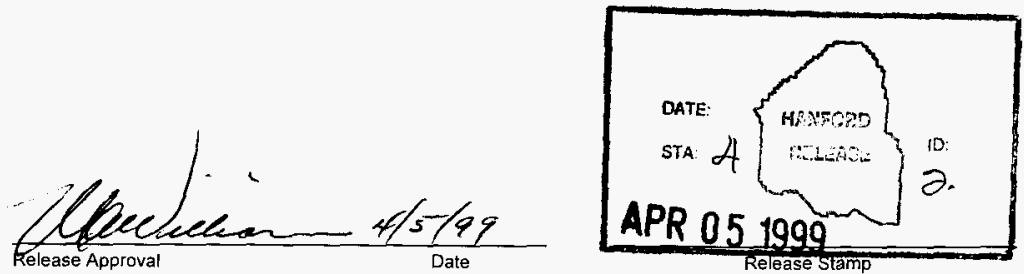

\section{Approved For Public Release}


HNF-3323

Revision 0

\section{Tank Waste Remediation System Nuclear Criticality Safety Inspection and Assessment Plan}

M. C. Brady Raap

DE\&S Hanford, Inc.

T. S. Vail

Waste Management Federal Services of Hanford, Inc.

Date Published

April 1999

Prepared for the U.S. Department of Energy

FUOR DANHEL HANFORD, InKC.

P.O. Box 1000

Richland, Washington

Hanford Management and Integration Contractor for the

U.S. Department of Energy under Contract DE-AC06-96RL13200 


\section{CONTENTS}

1.0 PURPOSE

2.0 SCOPE

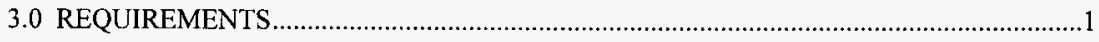

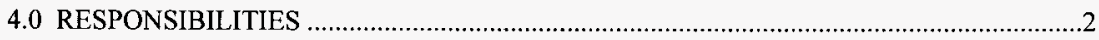

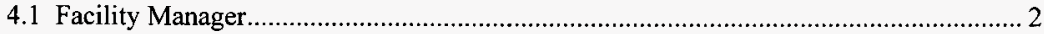

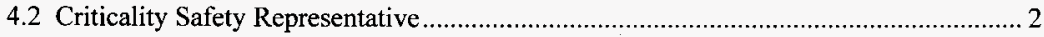

4.3 Facility Safety Representative............................................................................... 3

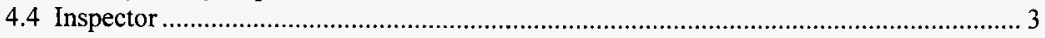

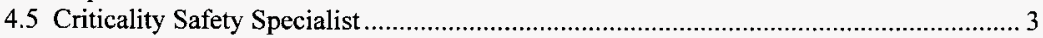

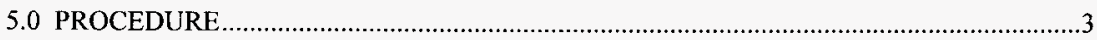

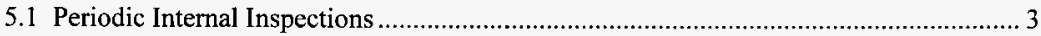

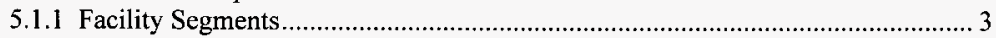

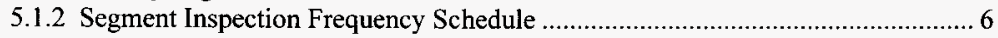

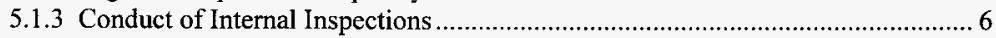

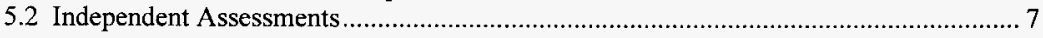

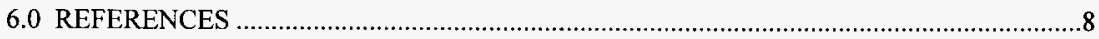

APPENDICES

A RECOMMENDED LINES OF INQUIRY FOR INTERNAL INSPECTIONS..................A-1

B TANK WASTE REMEDIATION SYSTEM PERIODIC SAFETY INSPECTION

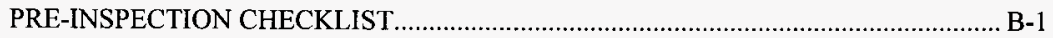

C TANK WASTE REMEDIATION SYSTEM PERIODIC CRITICALITY SAFETY INSPECTION 
HNF-3323 Rev. 0

\section{LIST OF TERMS}

CSER

CSR

CSS

DCRT

FEB

FSR

IMUST

MISF

TSR

TWRS
Criticality safety evaluation reports

Criticality Safety Representative

Criticality Safety Specialist

Double-Contained Receiver Tank

Facility Evaluation Board

Facility Safety Representative

Inactive Miscellaneous Underground Storage Tanks

Miscellaneous Inactive Storage Facilities

technical safety requirements

Tank Waste Remediation System 


\subsection{PURPOSE}

This plan provides a management approved procedure for inspections and assessments of sufficient depth to validate that the Tank Waste Remediation System (TWRS) facility complies with the requirements of the Project Hanford criticality safety program, HNF-PRO-334, Criticality Safety General, Requirements.

\subsection{SCOPE}

The scope of this plan includes the requirements and responsibilities for periodic internal inspections, periodic independent inspections and independent assessments. This plan contains the structure that integrates observation, assessment, corrective action, and lessons learned activities for continuous improvement, according to the guidance contained in HNF-IP-0842, Tank Waste Remediation Systems Administration, Volume I, Section 2.10, "Management Assessment Program".

\subsection{REQUIREMENTS}

The TWRS is classified as a "limited control facility" according to the definition in HNF-PRO-334, Criticality Safety General, Requirements. The Site requirements for inspections and assessments are in HNF-PRO-548, "Criticality Safety Inspections and Assessments." Three types of inspections are specified: 1) periodic internal inspections, 2) periodic independent inspections, and 3) annual independent assessments. TWRS specific requirements for inspections are contained in HNF-IP-1266, Tank Farm Operations Administrative Controls, Chapter 5.7, "Nuclear Criticality Safety", Rev 1A.

A technical evaluation of the phenomenological aspects of the receipt and storage of fissile material (waste) at TWRS led to the conclusion, documented in HNF-SD-WM-BIO-001, Tank Waste Remediation System Basis for Interim Operation, Chapter 5.3.2.1, "Nuclear Criticality" that a criticality accident at TWRS is "beyond extremely unlikely." The TWRS criticality safety program, therefore, consists of administrative controls designed to protect against altering the waste inventory in a way that could increase the probability of a criticality accident. Because the phenomenological aspects of waste receipt and storage that form the basis for the control selection are not directly observable during facility inspections, the verification of requirements implementation and the measurement of program effectiveness are achieved primarily by a documentation review. Therefore, the inspection and assessment frequencies suggested in HNF-PRO-548, have been modified by the waiver process for HNF-PROs as follows:

1. Internal inspections will be conducted semi-annually (twice per calendar year).

2. No separate independent inspections will be conducted. The independent Facility Safety Representative (FSR) will participate in or self-perform selected internal inspections. The scope of independent inspections suggested in HNF-PRO-548 has been incorporated into the scope of the internal inspections specified in this plan. 
HNF-3323 Rev. 0

3. Independent assessments will be conducted as a minimum bi-annually (once within two calendar years). The Facility Manager will determine if additional assessments are necessary based on conditions in TWRS.

\subsection{RESPONSIBILITIES}

The responsibilities for implementation of TWRS criticality inspections and assessments are as follows:

\subsection{FACILITY MANAGER}

The TWRS facility manager is responsible for ensuring:

1. Inspections are conducted in accordance with the frequency stated in this plan.

2. This plan is reviewed annually and changes or modifications to the facility are incorporated.

3. Personnel performing independent assessments are independent of Tank Waste Operations.

4. The scope and frequency of independent assessments are based on the criticality accident risk and level of work activity with fissionable material.

5. The implementation of any necessary corrective action, including risk ranking, root cause, and lessons learned, as required.

\subsection{CRITICALITY SAFETY REPRESENTATIVE}

The TWRS Safety Representative (CSR) shall:

1. Review inspection checklists and ensure that criticality safety issues are adequately addressed.

2. Prepare and maintain facility segment inspection frequency schedule. (see Section 5.1.2)

3. Interface with inspection and assessment teams to coordinate activities and to resolve criticality safety concerns.

4. Approve periodic internal inspections.

5. Ensure inspection reports conform to requirements.

6. Ensure inspection reports are distributed to the appropriate level of management. 


\subsection{FACILITY SAFETY REPRESENTATIVE}

The TWRS Facility Safety Representative (FSR) shall:

1. Provide the formal designation that personnel who will perform inspections are knowledgeable of criticality safety.

2. Participate in or self-perform selected internal inspections.

\subsection{INSPECTOR}

The Inspector shall:

1. Perform inspections in accordance with this plan.

2. Immediately notify management of any safety concerns identified during the inspection.

3. Issue inspection report.

\subsection{CRITICALITY SAFETY SPECIALIST}

The Criticality Safety Specialist (CSS) shall:

1. Participate in all independent assessments.

\subsection{PROCEDURE}

\subsection{PERIODIC INTERNAL INSPECTIONS}

The physical and administrative scope of TWRS is large and complex. The quantity and complexity of the fissionable material storage areas support a verification of compliance with criticality safety requirements. However, the criticality accident risk does not support an internal inspection of all aspects of the facility on a semiannual frequency. Therefore, internal inspections will be conducted using "facility segments." Recommended lines of inquiry to be used during the conduct of internal inspections are found in Appendix A.

\subsubsection{Facility Segments}

For purposes of this procedure the areas of TWRS where fissionable material is either stored or transferred are considered facility segments. Facility segments where fissionable material movement has recently occurred or is planned in the near future shall be included in the scope of inspections. This also includes the administration of waste transfers from waste generators, the independent verification of waste composition, and the plutonium inventory tracking system. Because the receipt and storage of waste is not directly observable during facility inspections, the verification of requirements implementation is achieved by a documentation review. 
If fissionable material has not been moved and no movement is planned in the facility segments, the inspections shall review administrative aspects of the program.

TWRS is grouped into facility segments according to operations conducted as follows:

1. Waste storage tanks and ancillary equipment.

\section{Description:}

This facility segment includes areas which either are actively engaged in the movement of fissionable material or have a high potential for moving fissionable material. This includes all double-shell and single-shell waste storage tanks, plus connecting piping, diversion boxes, catch tanks, ventilation systems, pumps, and instrumentation and waste receiving facilities.

Operational Areas:

Waste Tanks -- 149 single-shell and 28 double-shell tanks

Waste Transfer System (including process pits, diversion boxes, vault pits, cleanout boxes, and transfer lines)

Catch Tanks

204-AR Waste Unloading Facility

Tank 241-C-106 Waste Retrieval Sluicing System, Project W-320

Scope of Inspection:

Recommended lines of inquiry for this segment are Nos. 1, 3, 6, 9, 13, 16, 17, and 18 from Appendix A.

2. Double-Contained Receiver Tanks (DCRT) and ancillary equipment.

\section{Description:}

The DCRT facility segment includes the salt well receivers, transfer piping (e.g. from the SST to the DCRT), associated diversion boxes, catch tanks, pumps, ventilation systems, instrumentation, and buildings. This facility segment includes administration of waste transfers from non-tank farm waste generators whose waste is received in a DCRT

\section{Operational Areas:}

244-AR Vault

244-CR Vault

244-BX

244-A Lift Station

244-TX

244-U

244-S 


\section{Scope of Inspection:}

Recommended lines of inquiry for this segment are Nos. 1, 2, 3, 5, 10, 15, and 18 from Appendix A.

3. Miscellaneous Inactive Storage Facilities (MISF) and Other Inactive Facilities.

\section{Description:}

This facility segment includes the MISF, which is comprised of Inactive Miscellaneous Underground Storage Tanks (IMUST), and inactive aboveground miscellaneous storage tanks. Above and below ground tanks may be radioactive or nonradioactive, only the radioactive tanks are subject to criticality safety inspections. Other inactive facilities include the inactive evaporators and structures, which have small quantities of plutonium, but are not being operated and are unlikely to receive any additional fissionable material.

\section{Operational Areas:}

IMUST listed in WHC-SD-SQA-CSA-300004, "Criticality Safety Review for Inactive Miscellaneous Underground Storage Tanks."

2727-W Sodium Storage Facility*

213-W Dry Waste Compactor Facility

Vertical Storage Units within Tank Farm Boundaries

Grout Facility*

209-E Facility

Inactive Evaporators (242-T and 242-S)

* Inspected to ensure no fissionable material is brought into these facilities

Scope of Inspection:

Recommended lines of inquiry for this segment are Nos. 1, 3, 7, 11, and 14 from Appendix A.

4. Ponds, cribs, and ditches

\section{Description:}

This facility segment includes ponds, cribs and ditches that contain greater than 15 grams (g) fissionable material and are the custodial responsibility of TWRS management.

Operational Areas:

216-A-8

216-A-30

216-A-37-2

216-B-3 (expansion ponds only)
$50 \mathrm{~g}$

$73.1 \mathrm{~g}$

$373 \mathrm{~g}$

$250 \mathrm{~g}$ 
Scope of Inspection:

Recommended lines of inquiry for this segment are Nos. 1, 3, 4, 8, and 12 from Appendix A.

\subsubsection{Segment Inspection Frequency Schedule}

Not all facility segments will be reviewed during each inspection. However, every facility segment and every operational area within the segment, will be inspected at least once in any five year period. To assure all segments are inspected at least once every five years the following will be performed:

1. A facility segment inspection frequency schedule will be initially prepared by the CSR. It will show each facility segment and operational area and the last inspection date for each.

2. The schedule will be reviewed prior to each inspection to help select facility segments and operational areas to inspect.

3. The facility segment inspection frequency schedule will be updated upon completion of each inspection. The updated schedule will be attached to the inspection report.

\subsubsection{Conduct of Internal Inspections}

1. Personnel who are internal to the TWRS organization generally perform periodic internal inspections. The inspector is the CSR or any other person who is knowledgeable in criticality safety. The signature of the FSR on the inspection report satisfies the requirement that an inspector other than the CSR is knowledgeable in criticality safety. Periodically, the FSR will participate in or self-perform internal inspections.

2. The Pre-Inspection Checklist, Appendix B, shall be completed before the internal inspection. The lines of inquiry which are to be pursued will be noted on the checklist. Recommended lines of inquiry are listed in Appendix A. Additional lines of inquiry may be added by the inspector(s) based on their knowledge and existing facility segment conditions.

3. The results of the inspection shall be recorded on the TWRS Periodic Criticality Safety Inspection, Appendix C. The completed Appendix B checklist will be attached to the report.

4. The facility segment frequency schedule will be updated to show the segments just inspected and will be attached to the report.

5. Deficiencies identified during the inspection shall be analyzed and resolved with attention commensurate with the relative risk of the issue according to HNF-IP-0842, Tank Waste Remediation Systems Administration, Volume I, Section 2.4, "Corrective Action Management". 
HNF-3323 Rev. 0

\subsection{INDEPENDENT ASSESSMENTS}

Formal criticality safety assessments shall be conducted on the TWRS in the frequency specified in Section 3.0, Requirements. The Facility Manager shall ensure that personnel performing the assessment are independent of Tank Waste Operations and that a CSS is a member of the assessment team.

The assessments shall include the following:

1. Compliance with criticality safety related technical safety requirements (TSRs) or other aspects of the facility safety bases.

2. Internal administrative practices (assessments and inspections, training, including jobspecific training and records)

3. Changes to:

CPSs and postings

Criticality safety evaluation reports (CSERs)

Operating procedures that affect criticality safety

4. Organization and staffing

5. Occurrences or events relating to criticality safety

6. Compliance with PHMC and TWRS specific criticality safety policies and procedures

7. An inspection report shall be issued as a supporting document according to HNF-PRO-233, "Review and Approval of Documents."

8. The Facility Manager shall assure that identified deficiencies are analyzed and resolved with attention commensurate with the relative risk of the issue according to HNF-IP-0842, Tank Waste Remediation Systems Administrative, Volume I, Section 2.4, "Corrective Action Management." 


\subsection{REFERENCES}

FDH, 1997, Review and Approval of Documents, HNF-PRO-233, Rev. 0, Fluor Daniel Hanford, Inc., Richland, Washington.

FDH, 1997, Criticality Safety General, Requirements, HNF-PRO-334, Rev. 0, Fluor Daniel Hanford, Inc., Richland, Washington.

FDH, 1998, Criticality Safety Inspections and Assessments, HNF-PRO-548, Rev. 1, Fluor Daniel Hanford, Inc., Richland, Washington.

FDH, 1998,Tank Farms Operations Administrative Controls, HNF-IP-1266, Rev. 1A, Chapter 5.7, "Nuclear Criticality Safety," Fluor Daniel Hanford, Inc., Richland, Washington.

FDH, 1998, Tank Farms Operations Administrative Controls, HNF-SD-WM-BIO-001, Rev. 1, Chapter 5.3.2.1, "Nuclear Criticality,".Fluor Daniel Hanford, Inc., Richland, Washington.

FDH, 1998, Tank Waste Remediation Systems Administration, HNF-IP-0842, Rev. 4, Volume I, Section 2.4, "Corrective Action Management,".Fluor Daniel Hanford, Inc., Richland, Washington.

FDH, 1998, Tank Waste Remediation Systems Administration, HNF-IP-0842, Rev. 2, Volume I, Section 2.10, "Management Assessment Program, ".Fluor Daniel Hanford, Richland, Washington.

WHC, 1996, Criticality Safety Review for Inactive Miscellaneous Underground Storage Tanks, WHC-SD-SQA-CSA-300004, Westinghouse Hanford Company, Richland, Washington. 
HNF-3323 Rev. 0

APPENDIX A

RECOMMENDED LINES OF INQUIRY FOR INTERNAL INSPECTIONS 
HNF-3323 Rev. 0

This page intentionally left blank. 
HNF-3323 Rev. 0

\section{APPENDIX A \\ RECOMMENDED LINES OF INQUIRY FOR INTERNAL INSPECTIONS}

1. Criticality safety requirements documents have been reviewed (list documents reviewed).

2. The nuclear criticality safety analyses (CSERs) are fully documented.

3. The storage and transfer of fissionable material is in accordance to established procedures and criticality prevention specification requirements.

4. Copies of the inspection reports have been maintained for the past 5 years.

5. The criticality safety limits and controls are appropriate, based on observations and discussions with operation personnel either during the inspection or at other times during the inspection period.

6. The plutonium inventory database is maintained current under a controlled database umbrella.

7. The fissionable material measurement control program meets the requirements of 10 CFR 830, "Nuclear Safety Management."

8. Occurrence reports have been reviewed for nuclear criticality safety impact.

9. Personnel are qualified in accordance with criticality training requirements.

10. Operations supervisors are knowledgeable in those aspects of nuclear criticality safety relevant to the operations under their control.

11. Criticality safety inspectors are qualified.

12. The basic elements and control parameters of the TWRS nuclear criticality safety program satisfy the requirements of the mandatory American Nuclear Society's ANSI/ANS nuclear criticality safety standards.

13. Corrective measures are taken to prevent criticality hazards when problems are detected.

14. Management periodically participates in auditing the overall effectiveness of the nuclear criticality safety program.

15. Nuclear criticality safety evaluation reports contain sufficient detail, clarity, and lack of ambiguity to allow independent judgement of results.

16. The nuclear criticality safety program staff is familiar with all operations requiring nuclear criticality safety controls. 
HNF-3323 Rev. 0

17. Before the start of new or significantly modified operations, an independent assessment confirms the adequacy of the criticality safety evaluation

18. Facility Evaluation Board (FEB) reports of non-TWRS Waste Generators have been reviewed, 
HNF-3323 Rev. 0

APPENDIX B

TANK WASTE REMEDIATION SYSTEM PERIODIC CRITICALITY SAFETY INSPECTION PRE-INSPECTION CHECKLIST 
HNF-3323 Rev. 0

This page intentionally left blank.

B-2 
HNF-3323 Rev. 0

\section{APPENDIX B \\ TANK WASTE REMEDIATION SYSTEM \\ PERIODIC CRITICALITY SAFETY INSPECTION \\ PRE-INSPECTION CHECKLIST}

Date of Inspection:

Inspector:

$\overline{\text { Print }} \quad$ Signature

Formal Approval Designation of the Inspector:

( FSR)

Print Signature

Facility Inspection Frequency Schedule Reviewed

Facility Segment: Date last inspected:

Operational Area to be inspected: Date last inspected:

1. Summarize deficiencies reported from the previous inspection of this facility segment:

2. Summarize deficiencies reported from the previous inspection of this operational area:

3. List all deficiencies from previous inspections which are currently open:

4. List the lines of inquiry that will be pursued during the performance of this inspection (see Appendix A for the list of recommended lines of inquiries): 
HNF-3323 Rev. 0

This page intentionally left blank.

B-4 
HNF-3323 Rev. 0

\section{APPENDIX C}

TWRS PERIODIC CRITICALITY SAFETY INSPECTION 
HNF-3323 Rev. 0

This page intentionally left blank.

C-2 
HNF-3323 Rev. 0

\section{APPENDIX C}

TWRS PERIODIC CRITICALITY SAFETY INSPECTION

Inspector:

$$
\overline{\text { Print }} \quad \text { Signature }
$$

Formal Approval Designation of the Inspector:

(FSR)

Print

Signature

Facility Segment: Date last inspected:

Operational Area to be inspected: Date last inspected:

1. Are there any corrective actions from a previous inspection, which should have precluded the deficiencies, noted in this inspection?

2. Provide a discussion about how lessons learned could have prevented the deficiencies.

3. Status of items found on previous inspections:

4. New items for correction:

5. Discuss the determination of compliance with the requirements, limits, controls and lines of inquiry.

6. Facility inspection frequency schedule updated:

7. Required Distribution:

Assigned Actionees

Facility Segment Manager

Facility Criticality Safety Representative

Facility Safety Representative

HNF-PRO-548 Technical Authority 
HNF-3323 Rev. 0

This page intentionally left blank. 


\section{DISTRIBUTION SHEET}

To

Distribution

Project TitleMork Order

TWRS Nuclear Criticality Inspection and Assessment Plan
From

NS\&L/Criticality support

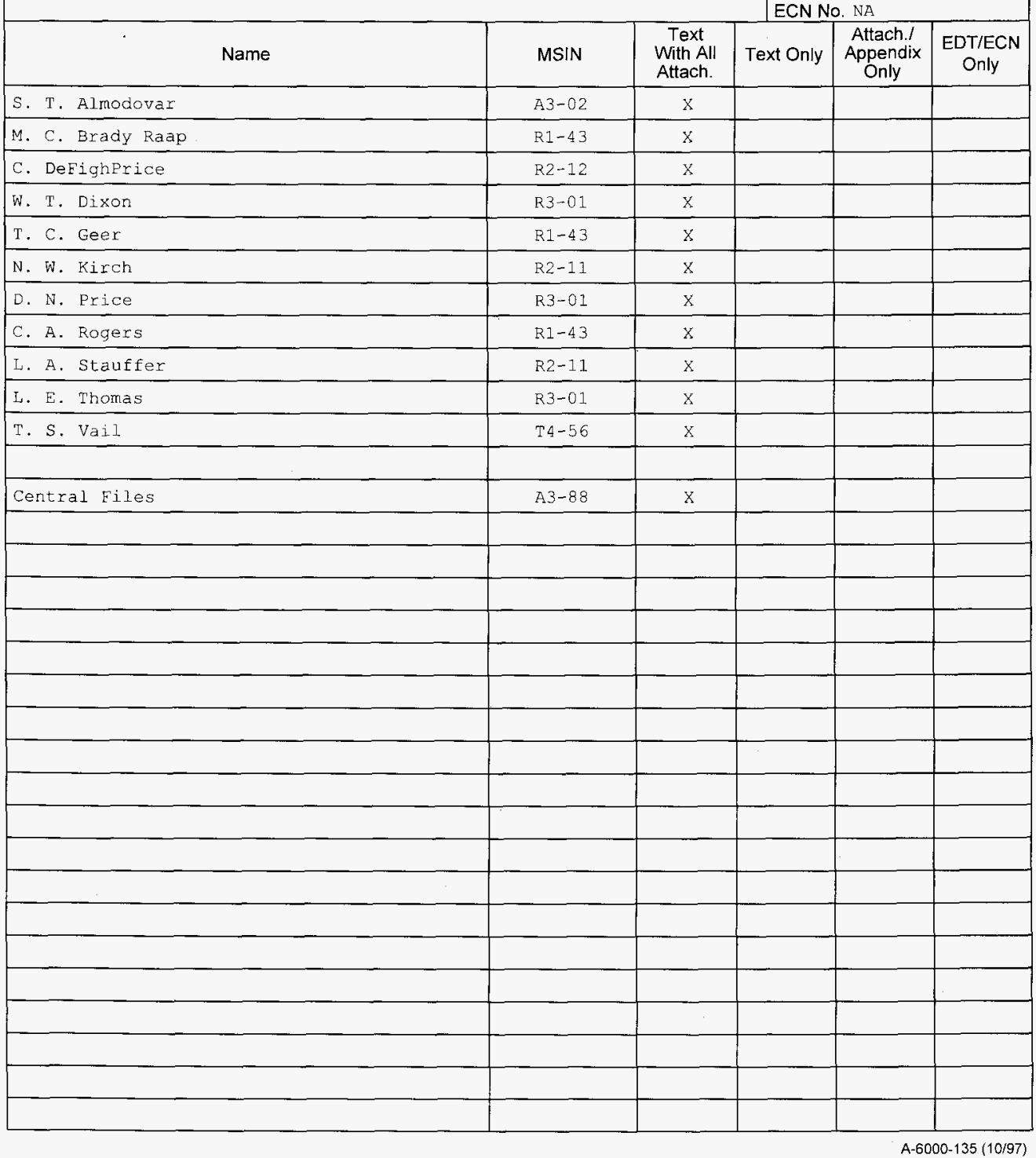

